\title{
BLINDING AS A PUNISHMENT: A STORY ABOUT SAUL IN THE OLD TESTAMENT AND THE IMAGE OF PAUL IN THE FINE ARTS
}

\author{
Vytautas Gudonis \\ Šiauliai University, Lithuania
}

\begin{abstract}
On the ground of theoretical research methods, the article estimates the image of Paul in the Old Testament and the fine arts. Examples of the fine arts are analysed in the paper as social phenomena. Interrelations between art and public events are revealed. Leaving issues of art criticism aside, pieces of art are analysed in the area of art sociology, aiming to notice reflections of historical reality and their impact on man beholding this. On the ground of analysis of replicas of 239 art works depicting a character of the Old Testament, Saul, it is attempted to answer the questions what episodes of this character's life were most commonly depicted in the fine arts, in which periods of historical development of art (Saul later was Christened as Paul, and afterwards proclaimed saint) the topic of Paul was the most popular, painters of which countries favoured this topic the most, what episodes of this character's life imposed painters, engravers and sculptors the most, why did this Biblical character receive more attention in the development of art history in comparison to other characters of the Old Testament.
\end{abstract}

Keywords: the Old Testament, blinding, conversion, fine art, image of Paul.

\section{Introduction}

Relevance of the topic, first of all, is determined by quite low investigation level of it. Qualitative research methods on art sociology have been applied in works by few scientists, to mention Chicago University (the USA) professor or art history, Barbara Maria Stafford, who generalised her research in 1993 in a monograph "Body Criticism" and revealed interrelations between medicine and the fine arts, Heidelberg University (Germany) Eye Clinics professor ophthalmologist, Wolfgang Jaeger (1976, 1679), and German typhlologist Dr Martin Jaedicke who in the 1980s would publish analyses of paintings by artists of various periods depicting the blind in a journal "Review of the European Blind". All these researchers attempted to find medical and social aspects in art works depicting disabled people (Gudonis, 2005). As the present article dissociates from art criticism, all aspect dealt with are treated in the paradigm of art sociology. Art sociology covers the entire system of interaction of art and society, including historical evolution of art and social functions, its spread and application (Prèskienis, 1989; Вахеметса, Плотников, 1968; Перов, 1970). Art sociologists try to understand changes of art in public life, to perceive art as a social phenomenon because art is inseparably social (Gaižutis, 1998). 
The aim of the research is to systematise knowledge on the character of the Old Testament, Saul, to analyse his image in fine art, to find out social aspects of the phenomenon of Paul.

Research methods: meta-analysis of philosophical, art criticism literature sources, analysis and interpretation of art pieces.

\section{Image of Saul in the Old Testament}

Who was Paul? This question is answered quite in detail by A. Men (1992). Paul, in Latin Paulos, in Jewish Shaul. Saul was born in the first decade of the $1^{\text {st }}$ century $\mathrm{AD}$ on the territory of present day Turkey, in the south of Asia Minor, Tarusus town, where the influences of the East and the West intermingled. He was raised under Jewish rules of belief in one God, strictly following pharisaic (in the good sense) fear of God. Relatives hoped that the boy would become a teacher knowing the Holy Scripture; therefore, they sent him to Jerusalem where he was learning at a famous rabbi Gamaliel. Gamaliel was a patriarch of the pharisaic group, in the good sense. These were pious people, enshrining traditions of the Old Testament. Saul or, Paul, remembers that among his contemporary youth together learning the Law of God he was the most diligent. And when he found out about the disposing with Stephen, he went there and, wishing to show his approval of this punishment, this disposing, he kept clothes of executioners would throw stones at the martyr. Nevertheless, at the moment, the exact moment when the first martyr was undergoing deaththroes, Saul's soul was disturbed by a doubt. Why were these people, the followers of Jesus Nazarene, so persistent, so strong? And, perhaps wishing to smother his doubts, he went to Damascus to smother the very beginnings of a new movement of Nazarenes (back then followers of Jesus were called Nazarenes). On his way to Damascus he experienced a moving miracle (Мен, 1992; Menis, 2001). This episode is described in the Old Testament quite vividly: "meanwhile Saul, breathing with threatening and killings against disciples of the Almighty, went to the head priest and obtained letters for synagogues of Damascus, in order having found men and women following this way could arrest them and bring to Jerusalem. When having almost approached Damascus, immediately he was enlightened with the light from the sky. Fallen down, he heard a voice: "Saul, Saul, why do you chase me?" He asked: "Who are you, the Almighty?" The reply was: "I am Jesus who you persecute. Stand up, go to the city; there you will be told what to do." Friend of his journey remained speechless: they heard the voice, but did not see anything. Saul rose up but, having opened his eyes, could not see anything. He was taken by hands and led to Damascus. For three days he stayed blind, neither drank nor ate. In Damascus he was living as a disciple named Ananim. The Almighty who had manifested to him said: "Ananim! He replied: "Here I am, the Almighty." The Almighty continued: "Get onto the street called the Straight Street, and in the house of Judas ask for a Tarusus man named Saul. Here he prays and sees a man 
in the vision; the man is called Ananim; he comes and puts his hands on him to make him see again." Ananim replied: "The Almighty, I have heard from many people about this man as much as he has done to your saints in Jerusalem. And here he has obtained authority from high priests to arrest all who call your name." The Almighty said to him: "Go because he is my selected tool who will carry my name to nations, kings and children of Israel. I will show him how much he will have to suffer in relation to my name." Thus, Ananim went to the mentioned house, hands on Saul and pronounced: "Brother Saul! The Almighty Jesus who manifested along the road sent me to make you able to see again and become full of Holy Spirit." And instantly as if exuviae fell off his eyes. He regained his eyesight and accepted christening." (Šventasis raštas, 1999, Apd 9, $1-19)$

Thus, Saul was christened and called Paul ("a small one") and was working as a missionary among pagan people. After the meeting of apostles, he went to many missions where new communities were established. When Paul brought collected donations to Jerusalem; due to christening against the Law he was under the threat of the lynch law, but he was rescued by Roman soldiers. After arrest and prison, Roman procurator Festus ordered to bring him, "leader of Nazarene sect", directly to Rome where he was killed (Birstein et al., 1999). The story of Saul-Paul is highly didactic. First of all, it suggestively demonstrates that a man can radically change. He became a diligent promoter of Christianity (Мифы народов мира 1982; Райт, 2010, Pažèraité, 2010; Мышцын, 2012). Here a metaphor, quite bringing pathos, applies: in order to see he needed to be blinded. The second truth states that the evil done to other people returns by the principle of a boomerang. Deaths that he brought returned to him by his premature, forced death. St Paul is treated by Catholics as a patron saint of Greece and Malta; on the $16^{\text {th }}$ of July 1914 Pius X announced Paul the patron saint of Greece. According to a legend, before conversion, he fell off a horse; therefore, he became a patron of horsemen; he is proclaimed as a patron of theologians because they have systemically displayed the Christian doctrine. Moreover, Paul is a patron of rope-makers; perhaps this is a reason why tiny ropes made of Cilician goat leather were used to weave tents, or that ropes required screwing (Lat. convertere - "unscrew" - also meaning "convert"). Besides, he was lowered down with ropes in a basket off Damascus's walls; therefore is a patron of basket-makers. As he bas beheaded by a shining sword, he became a patron of polishers and sword-makers. Paul protects from storms because he rescued a ship from a storm; he also protects from snake bites and poison because he survived after a snake bite in Malta. He is asked to help against becoming blind because he was cured after being blinded near the gate to Damascus (Lanzi, 2005). Having been the greatest enemy of Christians, Saul became a promoter of Christ's teaching (Рудинский, 1995; Райт, 2010). Everywhere we he appeared - in Antiochia, Ephesus, Galatia, Corinth, Athens, Crete, Philippines, Thessaloniki, Colos and elsewhere - Christian communities 
thrived (Фаррар, 1994; Мышцин, 2012). St Paul's Day is commemorated on the $29^{\text {th }}$ of June.

\section{Image of Paul in the Fine Arts}

Story of St Paul's life is reflected in the following plots:

1. Paul's calling (Šventasis raštas, 1999, Apd 9, 1-9).

2. Ananim returns eyesight to Saul (Šventasis raštas, 1999, Adp 9, 1019).

3. St Paul's escape from Damascus (Šventasis raštas, 1999, Apd 9, 2325).

4. Dispute between St Paul and St Peter in Anitochia ( ̌̌ventasis raštas, 1999, Gal, 2, 11-14).

5. Magician Elymus's embrace (Šventasis raštas, 1999, Apd, 13, 6-12).

6. St Paul and St Barnabas at Lystra (Šventasis raštas, 1999, Apd, 14, 818).

7. Imprisonment of St Paul in the town of Phillips (Šventasis raštas, 1999, Apd, 16, 16-26).

8. St Paul delivers sermons in Athens (Šventasis raštas, 1999, Apd, 17, 16-34).

9. St Paul delivers sermons in Ephesus (Šventasis raštas, 1999, Apd, 19, 19-20).

10. St Paul's vision (Šventasis raštas, 1999, 2 Cor 12, 1-4).

11. St Paul's rescue from a shipwreck near Malta island (Šventasis raštas, 1999, Apd 28, 1-6).

12. St Paul resurrects from the dead sons of the king in Antiochia.

13. The killing of St Paul (Ramoniené, 1997).

This list is missing the Paul's portrait gallery. Early Christianity was spreading throughout broad Roman Empire. An abundant community of Christians was established in Rome, when a conflict with the Emperor's power commenced in times of Emperor Claudius (AD 41-54). Bloody persecutions of Christians that started in times of Emperor Nero (AD 54-68) continued up until 313 (Grabar, 2003). We find some of the first images of Paul in the art of catacombs as a consequence of persecution of Christians. Such examples may be the following paintings: "Christ with Apostles Peter and Paul" in Santi Marcellino e Pietro catacombs (Rome, $3^{\text {rd }}-4^{\text {th }}$ c.) and portraits of Apostles Peter and Paul in Santa Tecla fresco in catacombs (Rome, $4^{\text {th }}$ c.) revealed in 2010.

Also, this period can be attributed with a drawing "Apostles Peter and Paul" made in gold on the bottom of a glass (Rome, $4^{\text {th }}$ c.). The same period is the date for the mosaic in Santa Costanza church, depicting Christ with Apostles Peter and Paul (Rome, $4^{\text {th }}$ c.). Also, Paul's image can be seen in medallions of San Vitale church, among other twelve Apostles painted on a vault of an arch (Ravenna, Italy, $6^{\text {th }}$ c.). Later, the image of Paul is often found in the period of early Byzantine art that began developing in the $5^{\text {th }}$ century and gave the 
beginning to the art of icons. Sublime Byzantine culture was spread throughout vast territories - from Asia Minor, Syria, Egypt, the Balkans to Armenia and Early Russia (Ankstyvosios Bizantijos epochos ikonos, 2014). Examples of the art of icons on the territories are attributed to the Byzantine School, however, all these regions, regarding their specificity, interpreted this art (Лидов, 1999). Thus, besides Byzantine art, Cretan, Macedonian, Old Novgorod, Vladimir, Suzdal, Yaroslavl, Pskov and other schools of icon painting appeared (Великие имена, 2007; Иконы (2013). The Russian School of icon painting is related with the names of Theophanes the Greek (ca. 1340-ca. 1410), Prochor of Gorodez $\left(14^{\text {th }}-15^{\text {th }}\right.$ c.), Andrei Rublev (ca. 1360-1428), Daniil Cherniy (ca. 1350-1428), Dionisy (ca. 1440-1502), Guriy Nikitin (1620-1691), Simon (Pimen) Ushakov (1626-1686), Fedor Zubov (1647-1689) (Гассель, 2008; Кондаков, 2011; Меркулов, 2012; etc.). Examples of paintings of Paul in the mentioned period are: Byzantine icon "Saint Paul, Peter, Nicolas, Jon the Evangelist" ( $7^{\text {th }}$ c., Sinai); "Apostles Peter and Paul Lead Martyrs of Rome to the City of Heaven", mosaic in Santa Prassede church (Rome, 11th c.); "Saint Paul", the $9^{\text {th }}$ century bas-relief in the Cathedral of Sts Peter and Paul in Maguelone, France; icon "Apostles Peter and Paul" from the Cathedral of St Sophia ( $11^{\text {th }}$ c., Novgorod, Russia); mosaic "Apostle Ananim Is Christening Paul" in Palatine Chapel (Palermo, Sicily, 12 ${ }^{\text {th }}$ c.); icon "Apostles Peter and Paul" in the Resurrection Church in Beloozersk (13th c., Russia); Byzantine icon "Apostles Peter and Paul" in Chora Church (14th c. Istanbul, Turkey); Theophanes's the Greek icon "Apostle Paul”, 1405; Theophanes's the Greek, Andrei Rublev's, Prochor's of Gorodez icon "Apostle Paul" (1408, Moscow, Russia); Daniil Cherniy's, Andrei Rublev's fresco "Apostles Peter and Paul Lead the Procession of the Self-Righteous to the Heaven" in Uspensky Cathedral (1408, Vladimir, Russia); Dionisy's icon "Apostle Paul”, (1502, Moscow), Simon Ushakov's icon “Apostles Paul and Peter", (17 ${ }^{\text {th }}$ c., Moscow). Paul is usually depicted together with Peter because they were the most famous individuals in the group of twelve apostles. We can draw an assumption that, after Christ and Virgin Mary with a Child, the third most popular place in iconography is taken by Apostles Peter and Paul. We can find their images in many churches, cathedrals not only named after them but also in other houses of prayer (Быкова, Гладышева et al. 2008). It only can be imagined about thousands of less famous painters' icons depicting saints, illuminated by lamp flame in homes of believers. Paintings of St Paul with or without St Peter have been created by representatives of both sacral and secular worlds. This Apostle was painted by Vincenzo Foppa (1430-1515), "St Paul”, 1458; El Greco (15411614), "Apostles Peter and Paul", "Apostle Paul", 1614; Guido Reni (15751642), "St Paul"; Pieter Poul Rubens (1577-1640), "St Paul"; Jusepe de Ribera (1591-1652), "St Paul”, 1637; Georges de La Tour (1593-1652), "St Paul", 1620; Diego Velazquez (1599-1660), "St Paul"; Rembrandt van Rijn (16061699), "Apostle Paul", "Apostle Paul in Prison", 1627, "Conversation of 
Apostles Peter and Paul", 1628, "St Paul and His Desk", 1629-1630; Angelica Kauffman (1741-1807), "St Paul", 1758, and other famous painters.

The second most popular theme in the fine art deals with the conversion of Saul or, Paul, into Christianity, in the Old Testament called "Paul's Calling". One of the earliest exampled in our collection of replicas is the $14^{\text {th }}$ century Italian painter's Lorenzo Veneziano's picture painted in 1370 in oil on small format $(26 \times 33 \mathrm{~cm})$ wood, entitled "The Conversion of St Paul". Not St Paul was pulled off the horse and blinded, but Saul who was the harshest enemy of followers of Jesus. This shows that part of painters had poor knowledge, were little interested in the Holy Scripture. The same mistake was also made in the title of the painting by $15^{\text {th }}$ century Italian painter Jacopo da Montagnana as well as majority of other painters. Later the mistake was applied numerous times. We will list painters who created and entitled their painting "The Conversion of Saul". This Biblical character was favoured by many painters. There is a fresco depicting the Conversion of Saul remaining in the Holy Saviour Church in Decani Monastery $\left(16^{\text {th }}\right.$ c. Kosovo, Serbia). This theme was favoured by both old masters, such as Giotto di Bondone (1267-1337), Andrei Rublev (ca. 1360$70-$ ca. 1430$)$, Andrea Vanni $\left(14^{\text {th }}\right.$ c.), Jacopo da Montagnana $\left(15^{\text {th }} \mathrm{c}\right.$.), Lorenzo Veneziano (1336-1372), Jean Fouquet (1415-1480), Giovanni Bellini (14301516), Luca Signorelli (1445-1523), Vincenzo Foppa (1430-1515), Hans Baldung Grien (1485/6-1545), Albrecht Duerer (1471-1528), Fra Bartolomeo (1475-1517), Michelangelo Buonarroti (1475-1564), Herri met de Bless (14801550), Benvenuto Tissi da Garofalo (1481-1559), Wolf Huber (1485-1553), Lorentz Brunster $\left(16^{\text {th }}\right.$ c. $)$, and $20^{\text {th }}-21^{\text {st }}$ century painters, such as Sadao Watanabe (1913-1996), Chris Cook $\left(20^{\text {th }}-21^{\text {st }}\right.$ c.), Eric de Saussure (b. 1925), Bruce Denny (b. 1967), Andrei Maksiutin (b. 1969). Analyses of some paintings mentioned here, such as by Raphael (1483-1520), Francesco Ubertini (14941557), Parmigiano (1504-1540), Lucas Cranach junior (1515-1580), Ludovico Carracci (1555-1619), Michelangelo Merisi de Caravaggio (1573-1610), Christoph Daniel Schenck (1633-1691) and other artists have already been presented to readers (Gudonis, 2001; 2002; 2006; 2007; 2007a; 2007b; 2008; $2008 \mathrm{a} ; 2008 \mathrm{~b} ; 2008 \mathrm{c} ; 2014)$. The contribution of Paul to promotion of Christianity is highly valued until the present day: in 2005 a golden medal has been coined to commemorate St Paul; the medal displays a picture of Michelangelo "The Conversion of St Paul". The medal of diameter of $35 \mathrm{~mm}$, weighing 34 grams was coined in 1,000 copies, each of them given a number.

Iconography reflects major episodes of Apostle Paul's life, especially the blinding-conversion of him and his beheading. He is depicted in mature age or old, with a beard, moustache and wreath of hair on his wide bald forehead; in the first images he holds a scroll of Christian teaching, and a sword that beheaded him became the most important attribute of him only in the $13^{\text {th }}$ century. A basket is another attribute; in it he was lowered down the wall of Damascus (Lanzi, 2005). Analysis of 239 replicas of our collected pieces of art 
on the theme of Paul shows that in iconography the most popular portrait of Paul was the one depicting him together with Apostle Peter. We find some of the first examples of the fine art on the theme of Paul dating back to the $3^{\text {rd }}-4^{\text {th }}$ centuries. The second most popular theme related to Paul deals with the blinding of him for vices and his conversion. This episode of Paul's life was commonly depicted by artists of the $16^{\text {th }}-17^{\text {th }}$ centuries. This period is the most numerous of replicas of our collection. This can be partially explained by the theme of Paul being part of sacral art. In the mentioned period newly built churches would be named after St Paul, decorated with the already announced saint, images of Paul. The theme of Paul's blinding-conversion was favoured by Italian painters. Also, French, Flemish, German, Dutch and English painters were not indifferent to the character of Paul. In the $20^{\text {th }}-21^{\text {st }}$ centuries we find only single painters from various countries; these painters usually return to the theme of Paul when illustrating Bible books for children. The contribution of Paul to promotion of Christianity is highly valued until present days. The image of Paul both in the Old Testament and the fine arts enhances the human belief in a possibility to change and become better. We seldom do this consciously - sometimes we need to become blind in order to see again.

\section{Summary}

Analysis of 239 replicas of our collected pieces of art on the theme of Paul shows that in iconography the most popular portrait of Paul was the one depicting him together with Apostle Peter. We find some of the first examples of the fine art on the theme of Paul dating back to the $3^{\text {rd }}-4^{\text {th }}$ centuries. The second most popular theme related to Paul deals with the blinding of him for vices and his conversion. This episode of Paul's life was commonly depicted by artists of the $16^{\text {th }}-17^{\text {th }}$ centuries. This period is the most numerous of replicas of our collection. This can be partially explained by the theme of Paul being part of sacral art. In the mentioned period newly built churches would be decorated with the already announced saint, images of Paul. The theme of Paul's blindingconversion was favoured by Italian painters. Also, French, Flemish, German, Dutch and English painters were not indifferent to the character of Paul. In the $20^{\text {th }}-21^{\text {st }}$ centuries we find only single painters from various countries; these painters usually return to the theme of Paul when illustrating Bible books for children. The contribution of Paul to promotion of Christianity is highly valued until present days. The image of Paul both in the Old Testament and the fine arts enhances the human belief in a possibility to change and become better.

\section{References}

Ankstyvosios Bizantijos epochos ikonos. http://orthodox-com.livejournal.com/2250.html (accessed on 22 August 2014)

Birnstein, U., Gutschera, H., Korne,r T., Ludvig, R., Maier, J., Schmid,t H. R.Thierfelde,r J. (1999). Krikščionybès kronika. Vilnius: Vaga. 


\section{SOCIETY. INTEGRATION. EDUCATION. Volume II}

Gaižutis, A. (1998). Meno sociologija. Vilnius: Enciklopedija.

Grabar, A. (2003). Krikščioniškoji ikonografija. Antika ir Viduramžiai. Vilnius: Aidai.

Gudonis, V. (2001). Parmigino. Paulius atsivertimas. Mūsu žodis, 12, 26.

Gudonis, V. (2002). Karavadžo. Šv. Pauliaus atsivertimas. Mūsų žodis, 4, 26.

Gudonis, V. (2005). Neregio išgydymo tema Biblijoje ir jos atspindžiai vaizduojamajame mene. Kürybos erdvès, 3, 53-62.

Gudonis, V. (2006). F. Ubertini. Šv. Paulius atsivertimas. Mūsǔ žodis, 11, 26.

Gudonis, V. (2007). L. Karačis. Paulius kelyje ị Damaską. Mūsų žodis, 6, 26.

Gudonis, V. (2007 a) J. P. Montero. Saulius atsivertimas. Mūsų žodis, 12, 26.

Gudonis, V. (2007b). Rafaelis. Elimo apakinimas. Mūsu žodis, 2, 26.

Gudonis, V. (2008). K. D. Šenkas Šv. Paulius atsivertimas. Mūsu žodis, 2, 26.

Gudonis, V. (2008 a). K. D. Šenkas. Šv. Paulius atsivertimas. Mūsuž žodis, 2, 26.

Gudonis, V. (2008b) J. Restout. Ananijas gražina regèjimą Šv. Pauliui. Mūsu žodis, 11, 26.

Gudonis, V. (2008c). L. Cranach jaunesnysis. Šv. Paulius atsivertimas. Mūsu žodis, 6, 26.

Gudonis, V. (2014). G. Clovio. Šv. Paulius prokonsulo akivaizdoje apakina Elimą. Mūsu žodis, $1,26$.

Jaeger, W. (1979). Augenvotive. Sigmaringen: Thorbecke.

Jaeger, W. (1976). Die Heilung des Blinden in der Kunst. Sigmaringen: Thorbeck.

Stafford, B. M. (1997). Body Criticism: Imaging the Unseen in Enlightenment Art and Medicine. Massachusetts Institute of Technology.

Krikščioniškosios ikonografijos žodynas (1997). Comp. Dalia Ramonienè. Vilnius: Vilniaus Dailès akademijos leidykla.

Lanzi, F., Lanzi, G. (2005). Šventieji globejjai ir ju simboliai. Vilnius: Alma littera.

Menis, A. (2001). Apaštalas Paulius. Artuma, 6, 4 - 8.

Pažėraitè, A. (2010). Paulius. Visuotiné lietuviu enciklopedija. T. XVII (On-Peri). Vilnius: Mokslo ir enciklopedijų leidybos institutas, 656-657.

Prèskienis, B. (1989). Sociologinis literatūros tyrinejimas. Vilnius: Lietuvos liaudies švietimo ministerijos leidybinè redakcinè taryba, 6 .

Šventasis raštas: Senasis ir Naujasis Testamentas (1999). Vertimas iš hebrajų, aramèjų ir graikų kalbų. Vilnius: Lietuvos vyskupų konferencija.

Быкова, М., Гладышева, Е., Горнатюк, М.А. и др. (2008). Иконы Владимира и Суздаля. Москва: Северный поломник.

Вахеметса, А., Плотников, С. (1968). Человек и искусство: Проблемы конкретносоииологических исследований искусства. Москва.

Великие имена: Симон Ушаков. (2007). Из избрания Государственной Третъяковской галереи. Москва: Юни Пресс.

Гассель, А. (2008). Провославная икона. Значение. Символика.Сюжетьл. Москва: АСТ, Олимп.

Кондаков Н. (2011). Иконы. Москва: ВММ.

Гладышева, Е., Игнашин,а Е., Комаров, а Ю. и др. (2008). Иконы Великого Новгорода XI - начало XVI веков. Москва: Северный поломник.

Иконьл (2013). Ed. Т. Терещенко. Москва: Дарь.

Каталог провославных икон. http://www.iconology.ru/group.php?gr=Y_1000 (accessed on 20 August 2014).

Лидов, А. М. (1999). Византийские иконь Синая. Москва: Христианский Восток.

Мен, А. (1992). История религии т. 7. Сын человеческий. Москва: Слово.

Меркулов, Д. (2012). 7 великих русских иконописцев. Культура, 7, 12.

Мифы народов мира (1982). Ред. С. А. Токорев. Т. 2. Москва: Энциклопедия.

Мышцын, В. Н. (2012)Учение св. апостола Павла о законе дел и законе веры. Москва: Академия фундаментальных исследований: богословие . 
Перов, Ю. В. (1970). Что такое сочиология искусства? Ленинград: Знание.

Райт, Н. Т. (2010). Что на самом деле сказал апостол Павел? Был ли Павел из Тарса основателем христианства? $3^{\text {rd }}$ ed. Москва..

Рудинский, Н. (1995). Жизнь и труды святого апостола Павла. Москва: Правило веры.

Словарь русских иконописцев XI-XVII веков (2003). Ed.-сотр. Кочетков И. А Москва: Индрик.

Фаррар, Ф. В. (1994). Жизнь и труды святого апостола Павла. Киев: “Богдана”. 